\title{
Experimental study of thermal efficiency of a solar air heater with an irregularity element on absorber plate
}

\author{
Foued Chabane $^{1,2^{*}}$, Noureddine Moummi ${ }^{1,2}$, Abdelhafid Brima ${ }^{1,2}$ \\ ${ }^{1}$ Mechanical Department, Faculty of Technology, University of Biskra 07000, Algeria \\ ${ }^{2}$ Mechanical Engineering Laboratory (LGM), Faculty of Technology, University of Biskra 07000, Algeria
}

Corresponding Author Email: fouedmeca@hotmail.fr

https://doi.org/10.18280/ijht.360311

Received: 27 September 2017

Accepted: 20 August 2018

\section{Keywords:}

semi-cylindrical baffle, thermal efficiency, outlet temperature, solar irradiation, flat plate

\begin{abstract}
The thermal performance of a solar air heater is presented with addition fins. In this work, we developed an experimental study on the thermal performance of a solar collector air with and without semi-cylindrical baffle. In trying to change the mass flow rates times for both configurations corresponding to tilt angle $\beta=37^{\circ}$, it represented the optimum tilt angle of the city of Biskra. The essential parameters are measurements of the outlet, an inlet and an ambient temperature and covering according to the influence of the wind velocity. Experiments on a solar collector designed for this purpose, have determined the thermal efficiency of solar collector with and without semi-cylindrical baffle to different flow intervals to actually follow the evolution of the outlet temperature of the air. The results provide the best thermal efficiency for a solar collector flat plate with semi-cylindrical baffle is increased by $19 \%$ that of without baffle.
\end{abstract}

\section{INTRODUCTION}

Production of thermal energy from solar energy is now one of the most promising technologies to meet the world's energy needs. Currently there are several million square meters of collectors and solar systems installed worldwide using the latest technologies. The largest share of research is devoted to the development of solar radiation, thermal performance point of view in general taking into account all the parameters that influence their behavior, we mean the design parameters (geometrical, thermo-physical and optical).

The conversion of solar energy into thermal energy is based on so-called solar systems. The systems can be flat or concentric. Applications such as, space heating, drying of food products depend on the outcome of these temperature sensors. Flat plate collectors are designed to give according to structural parameters and environment of so-called low and medium temperatures. Low heat exchange between the coolant and the absorber fluid are that the performance of these systems is limited. Several authors have contributed to improved performance;

Addition of baffles

Lower losses

Geometry of the absorber.

Improving the performance of solar flat plate collector's air by adding baffles:

Ahmed Zaid A. \& al. [1] Have conducted a theoretical and experimental study for comparing the performance of a solar plane in cases with and without obstacles. Different forms studied concern longitudinally curved fins delta (DCL), ogival arched longitudinally (OCL) and transverse-longitudinal (TL). Different forms studied both simple and interesting, concern.

The heat losses between the solar collector and its environment depend on its design. Indeed, they are a function of the temperature of its components
In order to minimize thermal losses toward the front of the absorber, Benyelles et al. [2] Proposed to place an insulating " silica air gel " above the absorber. They chose silica airgel for its properties, it is a solid material of low density ranging from 80 to $270 \mathrm{~kg} / \mathrm{m}^{3}$, transparent, porous (porosity of $35 \%$ to $90 \%$ ). Its refractive index is between 1.2 to 1.5 . of a thickness of the order of $20 \mathrm{~mm}$, normal solar transmittance is $90 \%$. Its thermal conductivity is about $0.02 \mathrm{~W} / \mathrm{m} \mathrm{K}$.

Zerrouki A. et al. [3] Conducted on a theoretical modeling of a solar collector air in conventional study design two passes (share airflow side of the absorber). They studied the event that the sensor is in a state such that the conditions are met Bliss. They established the thermal balance respectively on the transparent cover, the absorber and rear thermal insulation. They solved the equations obtained. They provided mathematical expressions of UL parameters Fr and F'. A graphical representation of these parameters was presented.

In order to improve the performance of solar air, Aoues K. et al. [4] presented an experimental study on a plane solar collector provided with different types of fins. The flow of coolant is under the absorber in the dynamic air stream of a $25 \mathrm{~mm}$ height between the absorber plate and a galvanized steel plate on the insulation. This vein is equipped with thin metal barriers rows welded perpendicularly to the flow of air. These obstacles have an inclined part of an angle $\alpha$ between $60^{\circ}$ and $120^{\circ}$. These baffles are positioned, spaced at a distance $d=10$ $\mathrm{cm}$ and $\mathrm{d}=5 \mathrm{~cm}$ in two configurations $\mathrm{A}$ and $\mathrm{B}$ which differ in the number of stored respectively equal to 152 and 256 .

In order to contribute to improving the performance of solar air plane sensors, Labed A. et al. [5] Conducted theoretical and experimental work on solar air collector's plate by introducing a different model of artificial roughness. The system studied is a single-pass collector consists of a single window, an absorber plate in galvanized steel, painted in matt black, with a galvanized steel back plate placed on the insulator and a rear 
polystyrene insulation. Artificial roughness are smaller channels, the base is trapezoidal in shape with a height of 25 $\mathrm{mm}$. They are placed between the two plates of galvanized steel.

Ben Slama [6] an experimental study conducted to see the airflow inside a solar air collector plane using the white smoke injected with the moving air circulating in the dynamic channel. This technique demonstrates the localization of the dead zones as well as the shape of the vortex generated by the baffles. These latter are placed in the moving air duct of 25 $\mathrm{mm}$ between the insulation and the absorber plate. Collector of dimensions $2 \times 1 \mathrm{~m}$. The visualization in the case of a solar collector without baffles. It should be noted a direct passage of air in the middle of the collector. In addition, the existence of dead zones.

Bahria S. et al. [7] conducted a theoretical and experimental study of a solar air plate. This sensor has been designed and built to the unity of development of solar equipment, " UDES

" based in Bousmail. The collector shows a portion of an indirect solar dryer prototype operating thermosiphon effect. The theoretical results provided by the model established in this study are compared with experimental measurements performed on this sensor for a characteristic day of May, in natural sunlight. They also investigated the influence of the increase in the number of rows of baffles on the thermal efficiency. They varied the number of rows of baffles July to October rows. The results obtained show that the exit temperature and the efficiency of the collector are considerably improved.

MF El-khawajah et al. [8] conducted experimental studies on the thermal performance of a solar collector air plate, double pass to 2, 4, and 6 attached baffles. Mesh of the layers has been used between the fins instead of a plate absorber. They studied the effect of varying the air flow on the outlet temperature and the thermal efficiency.

Ho-Ming Yeh, [9] studied theoretically the internal air recycling effect on the performance of the solar collector attached upward type air finned plane. The outlet temperature prediction models and sensor performance were deducted from the energy balances. Some literatures have used the thermal performance of a solar air heater with roughness elements on absorber plate and without fins for see the optimal point, and no forget the effect climate onto the collector, especially the ambient temperature, so we can be seen that ambient temperature is effect onto the thermal efficiency of solar collector [10-19]. F. Chabane \& al [20-31], Presents a study of heat transfer in a solar air heater by using new design of solar collector. The collector efficiency in a single pass of solar air heater without, and with using fins attached under the absorbing plate has been investigated experimentally the maximum efficiency obtained for the 0.012 and $0.016 \mathrm{~kg} / \mathrm{s}$ with, and without fins were $40.02,51.50 \%$ and $34.92,43.94 \%$. Some work reported the experiments undertaken to determine the effects of preparation methods and sample layer thicknesses on the solar drying kinetics of Oedogonium sp. The three preparation methods were not significantly different, while increasing the layer thickness was shown to decrease the drying rate [32]. The work was design a compact and durable LHS system capable of storing a substantial part of the heat produced during the combustion phase and to effectively release the stored heat to the room for 6 to 10 hours after the combustion phase ends [33].

\section{EXPERIMENTAL SETUP}

\subsection{Thermal analysis and uncertainty}

\section{Heat transfer coefficients}

The convective heat transfer coefficient hw for air flowing over the outside surface of the glass cover depends primarily on the wind velocity $V_{w}$. McAdams [34] obtained the experimental result as:

$h_{w}=5,67+3,86 . V_{w}$

where the units of $h_{w}$ and $V_{\text {wind }}$ are $W / m^{2} K$ and $\mathrm{m} / \mathrm{s}$, respectively. An empirical equation for the loss coefficient from the top of the solar collector to the ambient was developed by Klein [35]. The heat transfer coefficient between the absorber plate and the airstream is always low, resulting in low thermal efficiency of the solar air heater. Increasing the area of the absorber plate shape will increase the heat transferred to the air.

\subsection{Collector thermal efficiency}

The efficiency of a solar collector is defined as the ratio of the amount of useful heat collected to the total amount of solar radiation striking the collector surface during any period of time:

$\eta=\frac{Q_{u}}{I \times A}$

Useful heat collected in an air-type solar collector can be expressed as:

$Q_{u}=m \times C_{p} \times\left(T_{\text {out }}-T_{\text {in }}\right)$

where $\mathrm{Cp}$ is the specific heat of the air, A is the area of the collector. The fractional uncertainty about the efficiency from Eq. (2); is a function of $\Delta \mathrm{T}, \mathrm{m}$ and $\mathrm{I}$, considering $\mathrm{Cp}$ and $\mathrm{A}$ as constants.

With $m=V_{f} \times S$

\subsection{Description of solar air heater considered in this work}

The experimental results include the performance of the solar collector with and without baffles under the location of the Biskra city of Algeria, the solar collector is tested for a fixed duct air thickness of $40 \mathrm{~mm}$. The performance of the solar collector provides the base for comparison with different mass flow rates varying between 0.01 and $0.02 \mathrm{~kg} / \mathrm{s}$; for different days.

The photograph of experimental setup shown in Fig. 1, and the box of the collector is the views of the absorber plate in the collector box are shown in Fig. 3. The absorber plate made of galvanized iron sheet with a black selective coating. The plate thickness of collector was $1.2 \mathrm{~mm}$. The cover window type a Plexiglas of $3 \mathrm{~mm}$ thickness was used as glazing. Single transparent cover was used of collector. Thermal losses through the collector backs are mainly; due to the conduction across the insulation (thickness $2 \mathrm{~cm}$. After installation, the collector was left operating several days under normal weather conditions for weathering processes. 
The layout of the solar air collector studied is shown in Fig. 2, 3, 4. The collector served as the baseline one, with the parameters as:

The solar collecting area was $0.7 \mathrm{~m}$ (length) $\times 0.5 \mathrm{~m}$ (width);

The installation angle of the collector was $37^{\circ}$ from horizontal;

Thermal insulation board, EPS (expanded polystyrene board), with thermal conductivity $0.037 \mathrm{~W} /(\mathrm{m} \mathrm{K})$, was put on the exterior surfaces of the back and side plates, with a thickness of $20 \mathrm{~mm}$.

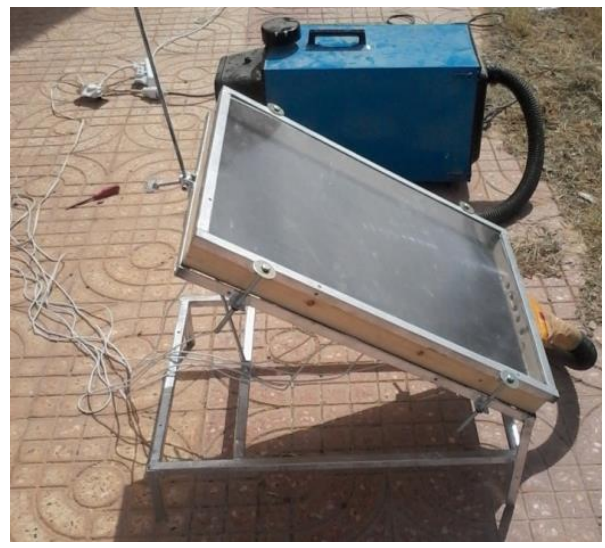

Figure 1. The photograph of experimental setup (without fins)

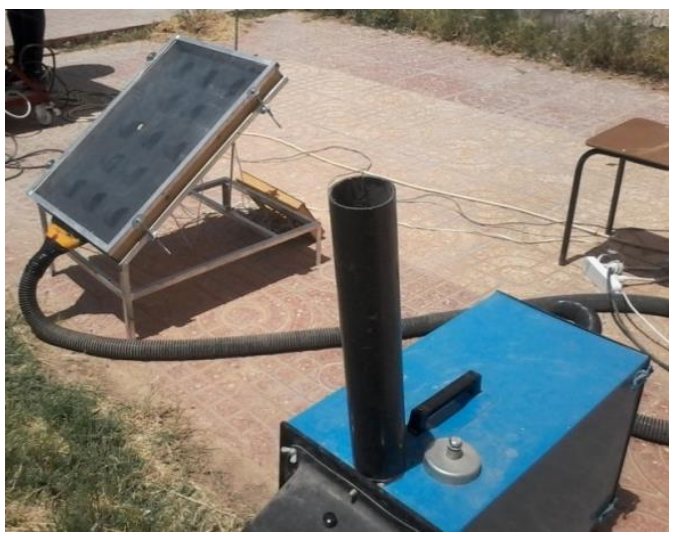

Figure 2. The photograph of experimental setup (with fins)

The absorber was of a plate absorption coefficient $\alpha=0.95$, the transparent cover transmittance $\tau=0.9$ and absorption of the glass covers, $\alpha_{\mathrm{g}}=0.05$;

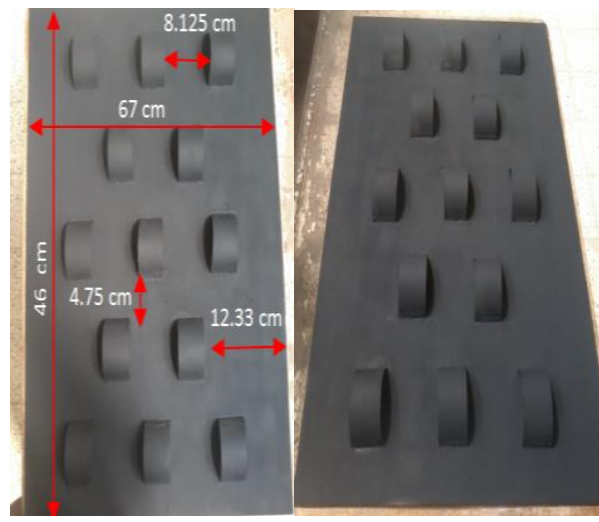

Figure 3. Absorber with baffles in semi-cylindrical shape
Experimental Study of the thermal performance of a solar collector with and without baffles

In April and May we have to do an experimental study on the thermal performance of a solar collector air plate with and without baffles (Figure $3 \& 4$ ). In our work we will change the mass flow rate three times for the sensor with and without baffles $\beta$ angle $=37^{\circ}$. The essential parameters are measurements of the outlet temperature and the inlet with the ambient and covering according to the influence of the wind speed.
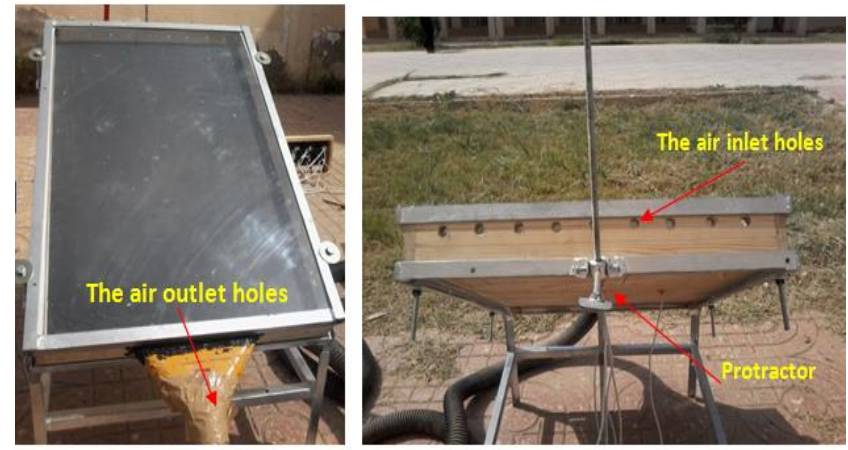

Figure 4. Installation of the solar flat plate collector without air baffles

\section{DISCUSSION}

The solar collector transforms solar energy - free and available - into useful energy producing hot air. A solar collector or solar panel is an element of a solar system for collecting solar energy to convert it into thermal energy and transfer it to a heat transfer fluid (air). The solar thermal collector: it consists of a black panel absorbing heat from the sun and transfers it to the air in the solar collector. There is basically a type of solar thermal collector air in our work. The simplest and cheapest plane sensor with a better solar yield because it gets more efficient solar radiation. The solar collector is mainly used for heating, sanitary hot air or the supplement to heating the house or building.

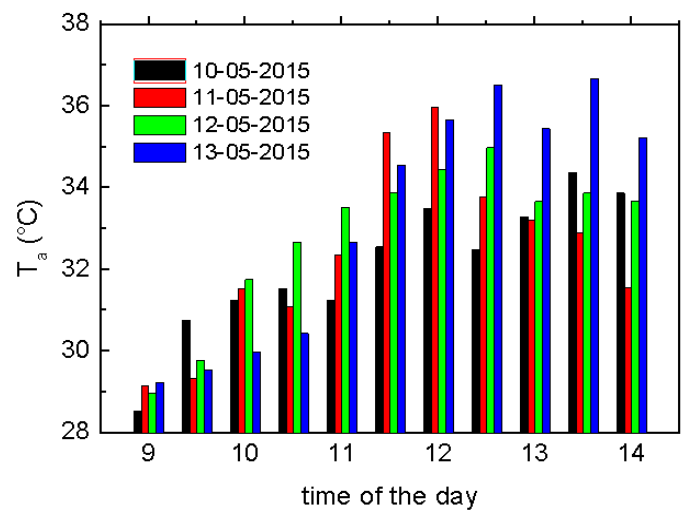

Figure 5. Ambient temperature as a function of time of the day

Figure 5 shows the time variation of ambient temperature after the four days from 10 to 13 May 2015. It is noted that there is a disturbance on the profile of the ambient temperature, which means the change is not stable (measurement site environment condition). 
Figure 6 shows the variation of the fluid temperature at the outlet of the solar collector according to true solar time for four days of study the site Biskra. It might be noted that the temperature of the fluid successively increases as the true solar time and takes the maximum value at solar noon and decreases in the direction of the sun bed. The output of the temperature profile, where $\mathrm{m}=$ mass flow $0.02 \mathrm{~kg} / \mathrm{s}$ with the presence of baffles is a bite maximum variation against the solar collector without baffles.

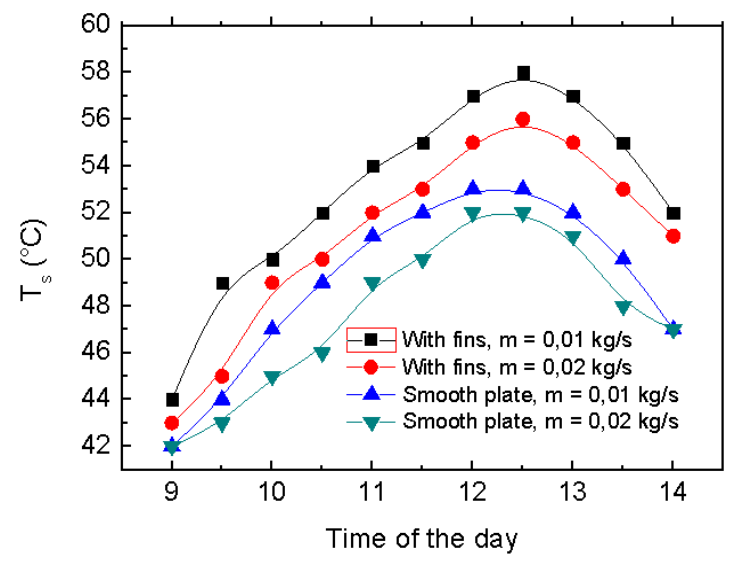

Figure 6. Outlet temperature as a function of time of the day

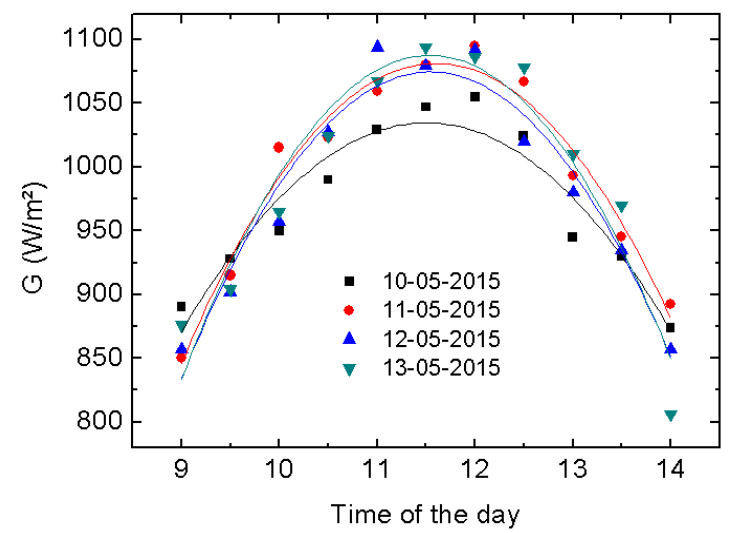

Figure 7. Global solar irradiation

Figure 7 shows the instantaneous variation of global solar radiation, according to the four different days. The figure shows the experimental evolution of the global solar radiation is gradually increased until it reaches its maximum value of $1075(\mathrm{~W} / \mathrm{m})$ at $12 \mathrm{TST}(13 \mathrm{~h}$ local $)$ and then fall until it reaches a minimum value at about $14 \mathrm{~h}$ : Local $30 \mathrm{~min}$.

We calculate the thermal efficiency of the solar collector with and without baffles games to put the physical parameters required to optimize the thermal performance of the solar collector. Figure 8 clearly shows that the performance of the optimization which our system with baffles in the case of mass flow reach the value $m=0.02 \mathrm{~kg} / \mathrm{s}$ gives a yield $\eta=74 \%$ by against baffled gives $\eta=55 \%$ that is to say, we gain $19 \%$ yield, so the result has improved our system.

Note that in the figure 10 changes in thermal efficiency of a solar air collector without baffles and with a function of flow rate. The first vote is intended that the yield is increased successively with the mass flow, and optimization is remarkable that shows the solar collector with a baffle is the best value.

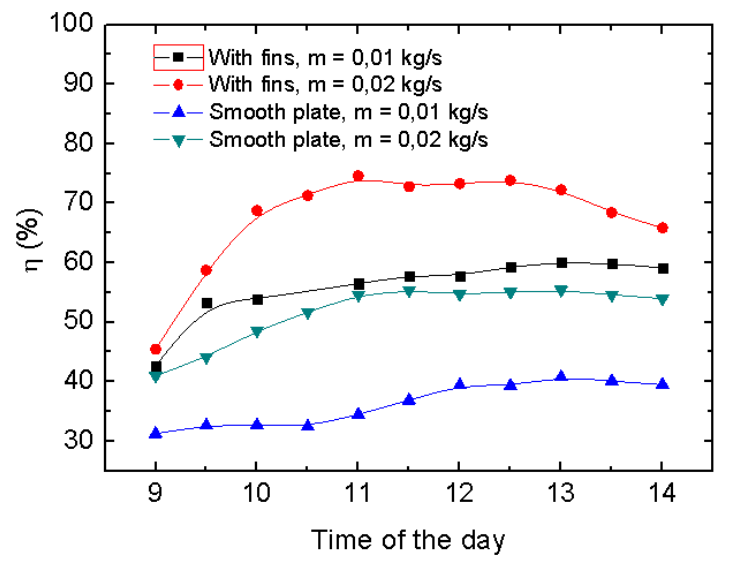

Figure 8. Thermal efficiency (with \& without baffles)

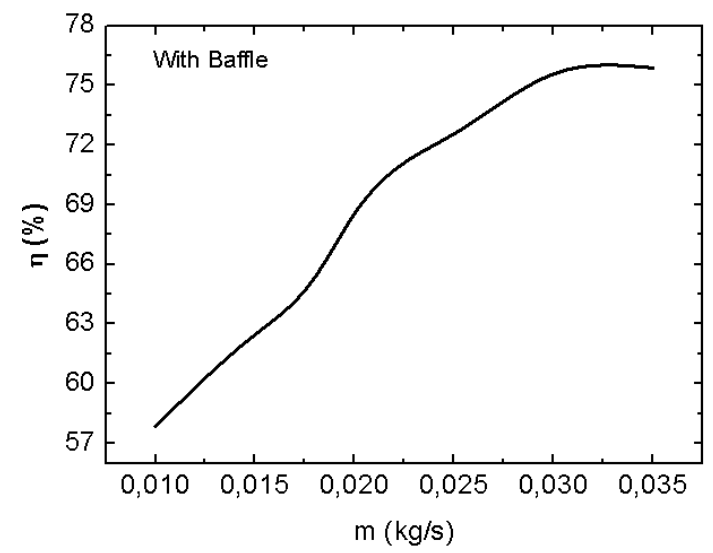

Figure 9. Thermal efficiency (with baffles) versus mass flow

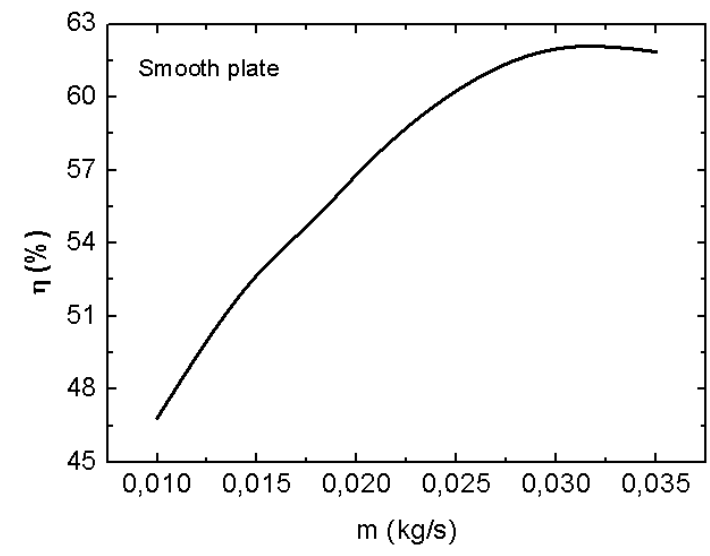

Figure 10. Thermal efficiency (without baffles) versus mass flow

\section{CONCLUSIONS}

During the months April and May we build a solar collector air plate, for meter games on the key physical parameters such as thermal efficiency, the outlet temperature and the roughness of the absorber plate, therefore the experimental results say thermal efficiency and the outlet temperature of a solar collector air plate with baffles is increased successively by one without baffles against the difference of $19 \%$ (thermal yield). 


\section{REFERENCES}

[1] Ahmed-Zaïd A, Moulla MS, Hantala JY. Des mons (2001). Improvement to the performance of solar collector air planes: Application to the drying of the yellow onion and herring. Revue des Energies Renouvelables 4: 69-78.

[2] Benyelles F, Benabadjia B, Benyoucef B, Ziani Z. (2007). Comparision between a Silica airgel collector and other flat collector. 13ièmes Journées Internationales de Thermique, Albi, France 28-30.

[3] Zerrouki A, Tedjiza B, Said N. (2002). Modeling thermal losses in a two-pass air solar collector. Rev. Energ. Ren 5: 49-58.

[4] Aoues K, Moummi N, Zellouf M, Moummi A, Labed A, Achouri E, Benchabane A. (2009). Improvement of the thermal performance of a planar air solar collectorexperimental study in the Biskra Region. Revue des Energies Renouvelables 12(2): 237-248.

[5] Labed A, Moummi N, Aoues K, Zellouf M, Moummi A. (2009). Theoretical and experimental study of a flat air solar collector equipped with a new artificial roughness form. Revue des Energies Renouvelables 12(4): 551-561.

[6] Slama RB. (2007). The air solar collectors: Comparative study, introduction of baffles to favor the heat transfer Solar Energy 81:139-149.

[7] Bahria S, Amirat M. (2013). Influence of the addition of longitudinal baffles on the performance of a solar collector. Revue des Energies Renouvelables 16(1): 5163.

[8] El-khawajah MF, Aldabbagh LBY, Egelioglu F. (2011). The effect of using transverse fins on a double pass flow solar air heater using wire mesh as an absorber. Solar Energy 85: 1479-1487.

[9] Yeh HM. (2012). Upward-type flat-plate solar air heaters attached with fins and operated by an internal recycling for improved performance. Journal of the Taiwan Institute of Chemical Engineers 43: 235-240.

[10] Chabane F, Moummi N, Benramache S. (2014). Experimental study of heat transfer and thermal performance with longitudinal fins of solar air heater. Journal of Advanced Research 5: 183-192.

[11] Chabane F, Moummi N, Benramache S, and Tolba AS. (2012). Experimental study of heat transfer and an effect the tilt angle with variation of the mass flow rates on the solar air heater. Int J Sci Eng Invest 1(9): 61-5.

[12] Chabane F, Moummi N, and Benramache S. (2012). Experimental performance of solar air heater with internal fins inferior an absorber plate: In the region of Biskra. Int J Energy Technol 4(33): 1-6.

[13] Chabane F, Moumm N, Brima A, Benramache S. (2013). Thermal efficiency analysis of a single-flow solar air heater with different mass flow rates in a smooth plate. Frontiers in Heat and Mass Transfer 4(1). http://dx.doi.org/10.5098/hmt.v4.1.3006

[14] Chabane F, Moumm N, Benramache S, Bensahal D, Belahssen O. (2013). Collector efficiency by single pass of solar air heaters with and without using fins. Engineering Journal 17(3): 43-55.

[15] Chabane F, Moumm N, Benramache S. (2012). Effect of the tilt angle of natural convection in a solar collector with internal longitudinal fins. Int J Sci Eng Invest 1(7): 13-7.

[16] Chabane F, Moumm N, Benramache S. (2013).
Experimental analysis on thermal performance of a solar air collector with longitudinal fins in a region of Biskra, Algeria. Journal of Power Technologies 93(1): 52-58.

[17] Chabane F, Moumm N, Benramache S, Belahssan O, Bensahal D. (2013). Nusselt number correlation of SAH. Journal of Power Technologies 93(2): 100-110.

[18] Chabane F, Moumm N. (2014). Heat transfer and energy analysis of a solar air collector with smooth plate. Eur. Phys. J. Appl. Phys 66: 10901.

[19] Chabane F, Hatraf N, Moumm N. (2014). Experimental study of heat transfer coefficient with rectangular baffle fin of solar air heater. Front Energy 8(2): 160-172.

[20] Chabane F, Moummi N, Benramache S, Bensahal D, Belahssen O. (2013). Collector efficiency by single pass of solar air heaters with and without using fins. Engineering Journal 7: 44-53.

[21] Chabane F, Moummi N, Benramache S. (2014). Heat transfer and energy analysis of a solar air collector with smooth plate. The European Physical Journal Applied Physics 66(1): 10901.

[22] Chabane F, Hatraf N, Moummi N. (2014). Experimental study of heat transfer coefficient with rectangular baffle fin of solar air heater. Frontiers in Energy 8(2): 160-172.

[23] Chabane F, Moummi N, Bensahal D, Brima A. (2014). Heat transfer coefficient and thermal losses of solar collector and Nusselt number correlation for rectangular solar air heater duct with longitudinal fins hold under the absorber plate. Applied Solar Energy 50(1): 19-26.

[24] Chabane F, Moummi N, Benramache S. (2014). Experimental study of heat transfer and thermal performance with longitudinal fins of solar air heater. Journal of Advanced Research 5(2): 183-192.

[25] Chabane F, Moummi N, Brima A, Benramache S. (2013). Thermal efficiency analysis of a single-flow solar air heater with different mass flow rates in a smooth plate. Frontiers in Heat and Mass Transfer 4(1).

[26] Chabane F, Moummi N, Benramache S, Bensahal D, Belahssen O. (2013). Effect of artificial roughness on heat transfer in a solar air heater. Journal of Science and Engineering 1(2): 85-93.

[27] Chabane F, Moummi N, Benramache S. (2013). Experimental analysis on thermal performance of a solar air collector with longitudinal fins in a region of Biskra, Algeria. Journal of Power Technologies 93(1): 52-58.

[28] Chabane F, Moummi N, Benramache S, Lemmadi FZ. (2013). Thermal performance optimization of a flat plate solar air heater. International Journal of Energy \& Technology 5(8): 1-6.

[29] Chabane F, Moummi N, Benramache S. (2012). Experimental study on heat transfer for a solar air heater and contribution the fins to improve the thermal efficiency. International Journal of Advanced Renewable Energy Researches 1: 9.

[30] Chabane F, Moummi N, Benramache S. (2012). Experimental performance of solar air heater with internal fins inferior an absorber plate: in the region of Biskra. International Journal of Energy \& Technology 4(33): 1-6.

[31] Chabane F, Moummi N, Benramache S. (2012). Effect of the tilt angle of natural convection in a solar collector with internal longitudinal fins. International Journal of Science and Engineering 1: 13-17.

[32] Hammond L, Bai L, Sheehan M, Walker C. (2018). Experimental analysis and diffusion modelling of solar 
drying of macroalgae - oedogonium sp. Chemical Engineering Transactions 65: 427-432. https://doi.org/10.3303/CET1865072

[33] Sevault A, Soibam J, Haugen NEL, Skreiberg Ø. (2018). Investigation of an innovative latent heat storage concept in a stovepipe. Chemical Engineering Transactions 65: 25-30. https://doi.org/10.3303/CET1865005

[34] Mcadams WH. (1961). Heat transmission. 2e édition.

[35] Klein SA, Beckman WA. (1979). A general desing method for colsed-loop solar energy systems. Solar Energy 22.

\section{NOMENCLATURE}

$\begin{array}{ll}\mathrm{m} & \text { Mass flow rate, } \mathrm{kg} \cdot \mathrm{s}^{-1} \\ \mathrm{C}_{\mathrm{P}} & \text { specific heat, } \mathrm{J} \cdot \mathrm{kg}^{-1} \cdot \mathrm{K}^{-1} \\ \mathrm{~T} & \text { temperature, }{ }^{\circ} \mathrm{C} \\ \mathrm{Q} & \text { enthalpy, W } \\ \mathrm{V} & \text { Speed, } \mathrm{m} \cdot \mathrm{s}^{-1}\end{array}$

Heat transfer coefficients, W. $\mathrm{m}^{-2} \cdot \mathrm{K}^{-1}$

Surface of the section pass, $\mathrm{m}^{2}$ Area of an abosorber plate, $\mathrm{m}^{2}$ Irradiation, W.m²

\section{Greek symbols}

$\begin{array}{ll}\alpha_{\tau} & \text { absorption coefficient } \\ \beta & \text { Slope angle, }{ }^{\circ} \\ \tau & \text { the transparent cover transmittance } \\ \eta & \text { Thermal efficiency, } \%\end{array}$

\section{Subscripts}

$\begin{array}{ll}\text { s, out } & \text { outlet } \\ \text { a } & \text { ambient } \\ \text { w } & \text { wind } \\ \text { f } & \text { fluid } \\ \text { in } & \text { inlet }\end{array}$

